\title{
Synthesis of Deuterium-Labeled Flavanones
}

\author{
Hitoshi Kagawa, ${ }^{*}, a$ Tetsuya Takahashi, ${ }^{a}$ Mariko Uno, ${ }^{a}$ Shigeru Ohta, ${ }^{b}$ and Yoshihiro Harigaya ${ }^{a}$ \\ ${ }^{a}$ Department of Organic Synthesis, School of Pharmaceutical Sciences, Kitasato University; 5-9-1, Shirokane, Minato-ku, \\ Tokyo 108-8641, Japan: and ${ }^{b}$ Graduate School of Biomedical Sciences, Hiroshima University; 1-2-3 Kasumi, Minami-ku, \\ Hiroshima 734-8551, Japan. Received February 26, 2004; accepted June 2, 2004; published online June 3, 2004
}

\begin{abstract}
Deuterium incorporation at the $\mathrm{C}-3$ position of flavanones was achieved by treatment of flavanones and 2'hydroxychalcones with $\mathrm{D}_{3} \mathrm{PO}_{4}$ and AcOD. We propose that the deuteration reaction mechanism for $2^{\prime}$-hydroxychalcones substrates is as follows. In the first step, $2^{\prime}$-hydroxychalcones cyclize to the corresponding flavanones by an intramolecular Michael-type reaction. Then deuteriums are incorporated into the flavanones via enolization.
\end{abstract}

Key words deuteration; flavanone; chalcone; metabolism; flavonoid

Flavonoids are polyphenolic compounds that are diverse in both chemical structure and chemical properties. Since flavonoids are naturally present in fruits, vegetables and tea, they are an integral part of the human diet. ${ }^{1)}$ Ingested flavonoids are absorbed by the gastrointestinal tract and have been found in body fluids and tissues. It is generally accepted that dietary flavonoids have important biological effects, such as decreasing the risk of death from coronary heart disease. ${ }^{2)}$ Other known biological properties of flavonoids include: antioxidant activity, ${ }^{3)}$ antiallergic activity, ${ }^{4)}$ and modulation of monooxygenase activity. ${ }^{5,6)}$ Recently two interesting properties of flavonoids have been reported. 1) Apparently, certain flavonoids can pass the blood-brain barrier because they were found to accumulate in rat brains. ${ }^{7)}$ 2) Certain flavonoids inhibit the cellular excretion of some drugs-a process mediated by P-glycoprotein. ${ }^{8,9)}$ Dietary flavonoids are probably ingested at sufficient levels to have significant pharmaceutical effects. Therefore, to understand the diverse pharmacological properties of flavonoids, their metabolism must be understood.

We have studied the metabolism of flavanones by cytochrome P450. This enzyme mediates the formation of flavones, flavanonols and isoflavones from the corresponding flavanones. We postulated that cytochrome P450 abstracts a hydrogen radical from the $\mathrm{C}-2$ or 3 position of the flavanone skeleton. ${ }^{10)}$ In plants, cytochrome P450 also participates in isoflavone biosynthesis. For example, Hakamatsuka et al. ${ }^{11)}$ reported that the formation of daidzein (isoflavone) from liquiritigenin (flavanone) was dependent on isoflavone synthase (cytochrome P450). It appears that a hydrogen radical abstraction from flavanones, as mediated by cytochrome $\mathrm{P} 450$, is a relatively general reaction in flavonoid metabolism and biosynthesis. To further clarify these reaction mechanisms, regio-selective deuterated flavanones would be useful tools.

Rasku et al. ${ }^{12,13)}$ reported the synthesis of polydeuteriumlabeled, polyhydroxylated flavones, flavonols and isoflavonoids with $\mathrm{D}_{3} \mathrm{PO}_{4} \cdot \mathrm{BF}_{3} / \mathrm{D}_{2} \mathrm{O}$ as the deuteration reagent. Because polydeuteration might cause significant and undesirable changes to the flavanones' cytochrome P450 binding properties and/or the cytochrome P450 catalytic activitiesin comparison to the non-deuterated flavanones - a regio-selective deuteration is needed. Therefore, we developed a new method for specific deuteration of the $\mathrm{C}-3$ position of flavanones.
Since $\mathrm{D}_{3} \mathrm{PO}_{4}$ and AcOD are commercially available and easily handled, these reagents are useful deuterating reagents and have been used for the experiments reported here. The method results in high yields of flavanone dideuteration and requires only short reaction times. Our experiments also allow us to suggest a reaction mechanism for the cyclization and the deuteration of $2^{\prime}$-hydroxychalcones.

\section{Results and Discussion}

As shown in Chart 1, monodeuterated chalcone $\mathbf{2}$ was synthesized from $4^{\prime}$-methoxychalcone $\mathbf{1}$ using Silva's method ${ }^{14)}$ (chemical yield, 71.7\%; deuteration yield, 94\%). Compound 2 was converted to the dideuterated flavanone 3 by deuteration with $\mathrm{D}_{3} \mathrm{PO}_{4}$ and $\mathrm{AcOD}$ (chemical yield, 74.4\%; dideuteration yield, 90\%). In an attempt to synthesize monodeuterated flavanone 5, monodeuterated chalcone $\mathbf{2}$ was treated with $\mathrm{H}_{3} \mathrm{PO}_{4}$ and $\mathrm{AcOH}$. Instead, the non-deuterated 4 '-methoxyflavanone 4 was generated in good yield (73.2\%). As the deuterium of monodeuterated chalcone 2 was exchanged for a hydrogen when the reaction was run in the presence of non-deuterated $\mathrm{H}_{3} \mathrm{PO}_{4}$ and $\mathrm{AcOH}$, deuteriums may be incorporated via enolization.

Given these results and the proposed reaction mechanism, we predicted that dideuterated flavanones could be readily synthesized from non-labeled $2^{\prime}$-hydroxychalcones or from flavanones. Non-labeled 2'-hydroxychalcones $(\mathbf{6}, \mathbf{1})$ or flavanones $(7,4)$ were converted to the corresponding dideuterated flavanones $(10,3,11)$ by treatment with $\mathrm{D}_{3} \mathrm{PO}_{4}$ and AcOD at $100^{\circ} \mathrm{C}$ (Chart 2 and Table 1). Chemical yields were determined as isolation yields. The structures and deuteration yields of the monodeuterated chalcones $(\mathbf{8}, \mathbf{2})$, the polydeuterated chalcone $\mathbf{9}$, the dideuterated flavanones $(\mathbf{1 0}, \mathbf{3})$ and the polydeuterated flavanone $\mathbf{1 1}$ were characterized by ${ }^{1} \mathrm{H}-\mathrm{NMR}$ spectroscopy. When the $\alpha$ position of the chalcones was deuterated, the ${ }^{1} \mathrm{H}-\mathrm{NMR}$ signals of the $\alpha-\mathrm{H}$ disappeared and the $\beta$-H signals became broad singlets, rather than doublets. For flavanones after deuteration, the signals of $\mathrm{C}-3-\mathrm{H}_{2}$ disappeared and those of $\mathrm{C}-2-\mathrm{H}$ became broad singlets, rather than doublet of doublets. To determine deuteration yields of flavanones, the signal of $\mathrm{C}-5-\mathrm{H}$ was used as the standard. In the case of chalcones, the signal of $\beta$ - $\mathrm{H}$ and $\mathrm{C}$ $3^{\prime}-\mathrm{H}$ were used as the standard for $\mathbf{6}$ and $\mathbf{1}$, respectively. The chemical and deuteration yields of the products are given in Table 1.

For the reaction of non-labeled 2'-hydroxychalcone 6 with 


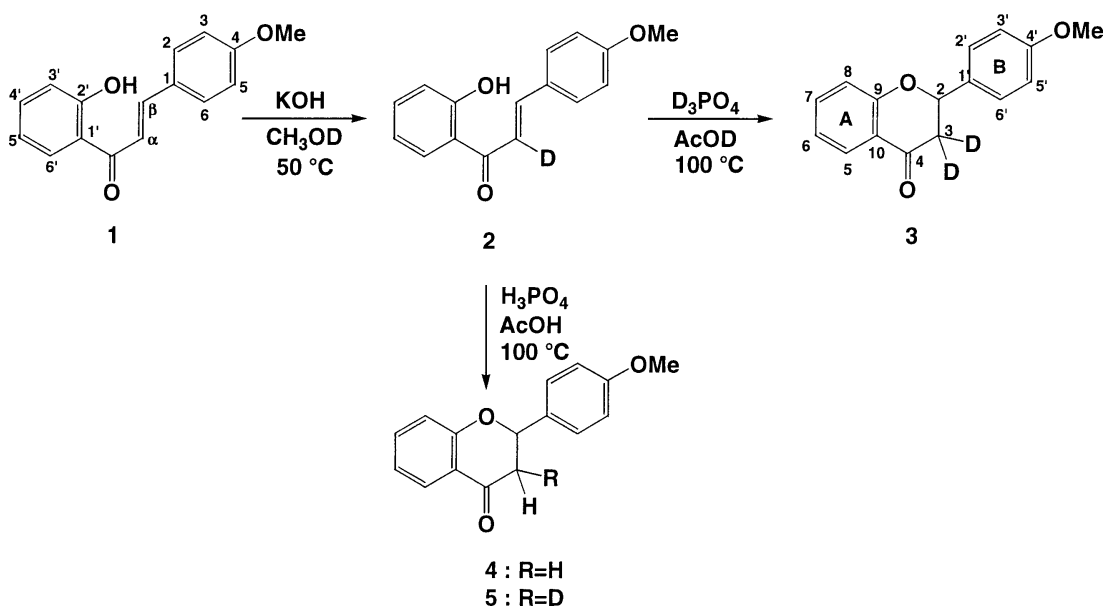

Chart 1. Acid-Catalyzed Deuteration of $2^{\prime}$-Hydroxy $\left[\alpha-\mathrm{d}_{1}\right] 4-$ methoxychalcone 2

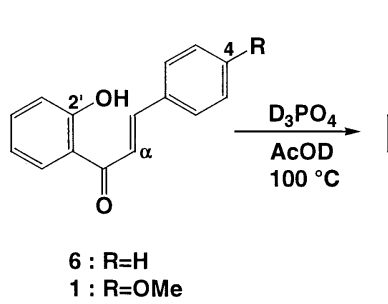

Chart 2. Deuteration Reactions of Non-labeled Chalcones and Flavanones

$\mathrm{D}_{3} \mathrm{PO}_{4}$ and AcOD, the deuteration yield of dideuterated flavanone 10 was large whether the reaction was run for 10 or $60 \mathrm{~min}$. However, for the $10 \mathrm{~min}$ reaction time, the chemical yield of $\mathbf{1 0}$ was less satisfactory $(16.7 \%)$, and large amounts of unreacted 6 remained $(82.8 \%)$. With non-labeled $2^{\prime}$-hydroxy-4-methoxychalcone $\mathbf{1}$ as the substrate, high levels of deuterium were incorporated at the C-3 position of the flavanone products $(3, \mathbf{1 1})$. Additionally, chemical yields of flavanones, with 1 as the substrate, were greater than with 6 as the substrate, no matter the reaction time. However, the quantity of polydeuterated flavanone $\mathbf{1 1}$ also increased significantly as the reaction time increased with $\mathbf{1}$ as the substrate. Analysis of the ${ }^{1} \mathrm{H}-\mathrm{NMR}$ spectrum of $\mathbf{1 1}$ proved that deuteration occurred at the C-3 position and at the carbons ortho to the methoxy group. In comparison with $2^{\prime}$-hydroxychalcone 6, the deuteration yield at the $\alpha$ position of $2^{\prime}$-hydroxy-4methoxychalcone 1 increased. Therefore, the 4-methoxy group, which is an electron-donating group, enhances deuteration at both the $\alpha$ position and at the ortho positions as well as increasing the extent of cyclization of the chalcone. Therefore, our method is also applicable when polydeuteration of flavonoids is desired.

Reaction of the non-labeled flavanone 7 with $\mathrm{D}_{3} \mathrm{PO}_{4}$ and AcOD gave good deuteration yields for both reaction times, as predicted by the proposed reaction mechanism. In comparison with substrate $\mathbf{6}$, monodeuterated $2^{\prime}$-hydroxychalcone $\mathbf{8}$ was obtained from 7 at high deuteration yields even after the shorter reaction time. Thus, the formation of compound $\mathbf{8}$ may have occurred by a retro-Michael-type reaction of the dideuterated flavanone $\mathbf{1 0}$. When non-labeled flavanone 7 was reacted only with AcOD, the desired dideuter-

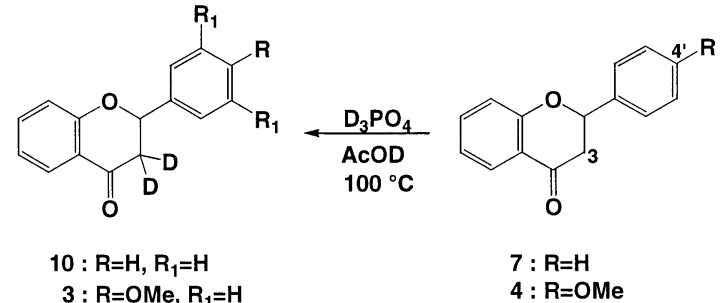

$11: R=O M e, R_{1}=D$

Table 1. Chemical and Deuteration Yields of Flavanones and 2'-Hydroxychalcones with $\mathrm{D}_{3} \mathrm{PO}_{4}$ and $\mathrm{AcOD}$

\begin{tabular}{|c|c|c|c|c|}
\hline Substrate & $\begin{array}{l}\text { Time } \\
(\mathrm{min})\end{array}$ & Product & $\begin{array}{l}\text { Chemical } \\
\text { yield }(\%)\end{array}$ & $\begin{array}{l}\text { Deuteration } \\
\text { yield }(\%)\end{array}$ \\
\hline \multirow[t]{2}{*}{6} & 10 & 10 & 16.7 & 90 \\
\hline & & 6 & 82.8 & - \\
\hline \multirow[t]{2}{*}{6} & 60 & 10 & 67.9 & 95 \\
\hline & & 8 & 19.2 & 9 \\
\hline \multirow[t]{2}{*}{1} & 10 & 3 & 72.0 & 92 \\
\hline & & 2 & 20.7 & 72 \\
\hline \multirow[t]{2}{*}{1} & 60 & 11 & 70.3 & $93(46)^{a)}$ \\
\hline & & 9 & 18.0 & $99(96)^{a)}$ \\
\hline \multirow[t]{2}{*}{7} & 10 & 10 & 91.6 & 89 \\
\hline & & 8 & 6.2 & 76 \\
\hline $7^{b)}$ & 10 & 7 & 88.9 & - \\
\hline \multirow[t]{2}{*}{$7^{c)}$} & 10 & 10 & 91.3 & 61 \\
\hline & & 6 & 3.5 & - \\
\hline \multirow[t]{2}{*}{7} & 60 & 10 & 87.1 & 85 \\
\hline & & 8 & 7.3 & 94 \\
\hline \multirow[t]{2}{*}{4} & 10 & 3 & 79.1 & 91 \\
\hline & & 2 & 16.2 & 87 \\
\hline \multirow[t]{2}{*}{4} & 60 & 11 & 77.6 & $95(26)^{a)}$ \\
\hline & & 9 & 15.0 & $94(59)^{a)}$ \\
\hline
\end{tabular}

a) Deuteration yield at $\mathrm{R}_{1}$. b) With only AcOD as the deuteration reagent. c) Reagents were $\mathrm{AcOH}$ and $\mathrm{D}_{3} \mathrm{PO}_{4}$.

ated flavanone $\mathbf{1 0}$ was not formed and non-deuterated flavanone 7 was recovered. If only $\mathrm{D}_{3} \mathrm{PO}_{4}$ was used as the deuteration reagent, little, if any, deuteration occurred (data not shown), because non-deuterated flavanone 7 is insoluble in $\mathrm{D}_{3} \mathrm{PO}_{4}$. When non-deuterated acetic acid $(\mathrm{AcOH})$ was present and $\mathrm{D}_{3} \mathrm{PO}_{4}$ used as the deuteration reagent, the deuteration yield at the C-3 position of $\mathbf{1 0}$ decreased because of hy- 
drogen-deuterium exchange between $\mathrm{D}_{3} \mathrm{PO}_{4}$ and $\mathrm{AcOH}$. Thus, deuteriums from $\mathrm{D}_{3} \mathrm{PO}_{4}$ were incorporated into the flavanones, while $\mathrm{AcOD}$ served as the solvent. Therefore $\mathrm{D}_{3} \mathrm{PO}_{4}$ and AcOD were necessary for the high incorporation rate of deuteriums.

Starting with $4^{\prime}$-methoxyflavanone $\mathbf{4}$, the deuteration yield at the C-3 position of $\mathbf{4}$ was large for both reaction times. But, as for deuteration of $\mathbf{1}$, an extension of the reaction time increased the deuteration at the carbons ortho to the 4'methoxy group. We propose that deuteration at the positions ortho to the methoxy group is caused by resonance involving the electron-donating group itself. Thus, for many flavonoids, with one or more electron-donating groups associated with the A and/or B-ring of the flavonoid skeleton, polydeuteration may be a general result when our method is used. Indeed, in a preliminary report, we showed that polydeuteration of 5-methoxyflavanone occurs at the carbons ortho (C-6) and para $(\mathrm{C}-8)$ to the methoxy group, as well as at the $\mathrm{C}-3$ position. ${ }^{15)}$ Mazur et $a l .{ }^{16)}$ reported that isoflavonoids from plantderived foods could be quantified using isotope dilution gas chromatographic-mass spectroscopy with polydeuterated isoflavonoids as internal standards. We expect that polydeuterated flavonoids, prepared by our method, can be used for identification and quantification of non-deuterated flavonoids derived from biological sources.

\section{Conclusion}

We report a new method for deuteration of non-deuterated chalcones and flavanones. We show that dideuterated flavanones and monodeuterated chalcones are readily prepared using $\mathrm{D}_{3} \mathrm{PO}_{4}$ and AcOD. Our results suggest a reaction mechanism for deuteration of $2^{\prime}$-hydroxychalcones. In the first step, 2'-hydroxychalcones cyclize to the corresponding flavanones by an intramolecular Michael-type reaction. Then, in a second step, deuteriums are incorporated at the C-3 position of flavanones via enolization. In our study of flavanone metabolism by cytochrome $\mathrm{P} 450$, we probed the reaction mechanism using C-3 deuterium-labeled flavanones. An intermolecular isotope effect was observed for the metabolism of dideuterated flavanones $(\mathbf{3}, \mathbf{1 0})$ and non-labeled flavanones $(4,7)$ to the corresponding 2,3-trans-flavanonols by cytochrome P450. ${ }^{10)}$ Therefore, these dideuterated flavanones are useful reagents for metabolic study of flavonoids.

In summary, we achieved a regio-selective deuteration at the $\mathrm{C}-3$ position of flavanones, and we proposed a reaction mechanism for the cyclization and the deuteration of $2^{\prime}$-hydroxychalcones. The deuteration reagents, $\mathrm{D}_{3} \mathrm{PO}_{4}$ and $\mathrm{AcOD}$, are commercially available and easily handled. Although applied only to chalcones and flavanones in this report, the method may be a general procedure for the introduction of deuteriums at positions $\alpha$ to ketones in other natural products. Additionally, in the case of these compounds with one or more electron-donating groups with aromatic rings in their structures, deuteration at the carbons ortho and/or para to the electron-donating groups may also occur when the reaction time is extended. Therefore, our deuteration method is also useful for polydeuteration of natural products with one or more electron-donating groups and/or ketones.

\section{Experimental}

Melting points were taken using a Yanagimoto hot-stage apparatus and are uncorrected. ${ }^{1} \mathrm{H}-\mathrm{NMR}$ spectra were recorded using a Varian VXR-300 or a $\mathrm{XL}-400$ spectrometer. ${ }^{13} \mathrm{C}-\mathrm{NMR}$ spectra were recorded using a Varian XL400 spectrometer. Mass spectra were obtained using a JEOL-JMX-DX 300 or a JEOL-JMS-AX505 HA mass spectrometer. Microanalyses were recorded using a Yanaco CHN corder MT-5. Thin-layer chromatography and preparative chromatography were run using silica gel 60 PF254 (Merck) with benzene as the mobile solvent. 2'-Hydroxychalcone $\mathbf{6}$ and flavanone 7 were purchased from Tokyo Kasei Kogyo Co., Ltd. (Tokyo, Japan) and Wako Pure Chemical Industries, Ltd. (Osaka, Japan) respectively.

General Procedure for Deuteration of Flavonoids To individual solutions of non-labeled chalcones (6 or $\mathbf{1})$ and of non-labeled flavanones (7 or 4) - all at quantities of $50 \mathrm{mg}$ - in AcOD $(0.5 \mathrm{ml}, 98$ atom\% D, SigmaAldrich Japan K. K.), $\mathrm{D}_{3} \mathrm{PO}_{4}(0.5 \mathrm{ml}, 99$ atom\% D, Sigma-Aldrich Japan K. K.) was added. The reaction mixtures were stirred at $100^{\circ} \mathrm{C}$ for $\mathbf{1 0}$ or $60 \mathrm{~min}$ under argon. After each reaction was finished, the mixture was treated with an ion-exchange resin (AMBERLYST ${ }_{\circledast}$ A-21 from ORGANO Co.), extracted with benzene, evaporated, and then purified by preparative TLC.

Preparation of $\mathbf{2}^{\prime}$-Hydroxy-4-methoxychalcone (1) A mixture of $2^{\prime}$-hydroxyacetophenone $(1.00 \mathrm{~g}, \quad 7.35 \mathrm{mmol}), \quad p$-anisaldehyde $(1.01 \mathrm{~g}$, $7.43 \mathrm{mmol})$, and $\mathrm{KOH}(4.17 \mathrm{~g}, 74.3 \mathrm{mmol})$ in ethanol $(100 \mathrm{ml})$ was stirred at room temperature for $20 \mathrm{~h}$. The reaction mixture was neutralized with acetic acid (10\% ethanolic solution) and evaporated. The residue was extracted with ethyl acetate and brine. The organic phase was dried over $\mathrm{Na}_{2} \mathrm{SO}_{4}$. The organic layer was then evaporated, and the residue was purified using column chromatography (silica gel, benzene $: n$-hexane $=1: 10$ ) to give $\mathbf{1}$ as yellowish needles (1.47 g; yield, 78.9\%). $R f=0.37$ (benzene : $n$-hexane $=1: 1$ ), mp: 95- $96{ }^{\circ} \mathrm{C}$ (EtOH) (lit., $\left.{ }^{17)} 95^{\circ} \mathrm{C}\right)$; IR $\left(\mathrm{CHCl}_{3}\right) \mathrm{cm}^{-1}: 1640(\mathrm{C}=\mathrm{O}) ;{ }^{1} \mathrm{H}-$ NMR $\left(400 \mathrm{MHz}, \mathrm{CDCl}_{3}\right) \delta: 12.933(1 \mathrm{H}, \mathrm{s}, \mathrm{OH}), 7.925(1 \mathrm{H}, \mathrm{dd}, J=1.5$, $\left.7.8 \mathrm{~Hz}, 6^{\prime}-\mathrm{H}\right), 7.912(1 \mathrm{H}, \mathrm{d}, J=15.0 \mathrm{~Hz}, \beta-\mathrm{H}), 7.636(2 \mathrm{H}, \mathrm{d}, J=8.7 \mathrm{~Hz}, 2,6-$ $\mathrm{Hs}), 7.547(1 \mathrm{H}, \mathrm{d}, J=15.0 \mathrm{~Hz}, \alpha-\mathrm{H}), 7.492\left(1 \mathrm{H}, \mathrm{ddd}, J=8.2,8.5,1.5 \mathrm{~Hz}, 4^{\prime}\right.$ $\mathrm{H}), 7.025\left(1 \mathrm{H}, \mathrm{dd}, J=8.2,1.0 \mathrm{~Hz}, 3^{\prime}-\mathrm{H}\right), 6.956(2 \mathrm{H}, \mathrm{d}, J=8.7 \mathrm{~Hz}, 3,5-\mathrm{Hs})$, $6.943\left(1 \mathrm{H}\right.$, ddd, $\left.J=1.0,8.5,7.8 \mathrm{~Hz}, 5^{\prime}-\mathrm{H}\right), 3.869$ (3H, s, 4-OMe); HR-EIMS $m / z$ : 254.0944 (Calcd. for $\mathrm{C}_{16} \mathrm{H}_{14} \mathrm{O}_{3}: 254.0943$ ); Anal. Calcd. for $\mathrm{C}_{16} \mathrm{H}_{14} \mathrm{O}_{3}: \mathrm{C}, 75.57, \mathrm{H}, 5.55$; Found: $\mathrm{C}, 75.32, \mathrm{H}, 5.61$.

Preparation of ( \pm )-4'-Methoxyflavanone (4) To a solution of 2'-hydroxy-4-methoxychalcone 1 (97.5 $\mathrm{mg}, 0.38 \mathrm{mmol})$ in acetic acid $(1 \mathrm{ml}), 1 \mathrm{ml}$ of phosphoric acid was added. The stirred reaction mixture was placed in a boiling water bath for $10 \mathrm{~min}$. The mixture was then poured into water and the precipitate was extracted with ethyl acetate. The organic layer was dried over $\mathrm{Na}_{2} \mathrm{SO}_{4}$ and evaporated to give an orange oil that was then purified by preparative TLC. These procedures gave 4 as colorless needles $(70.7 \mathrm{mg}$; yield, 72.5\%). $R f=0.30$ (benzene), mp: $93-94^{\circ} \mathrm{C}(\mathrm{EtOH})$ (lit., ${ }^{18)} 96-$ $\left.98^{\circ} \mathrm{C}\right)$; IR $\left(\mathrm{CHCl}_{3}\right) \mathrm{cm}^{-1}: 1690(\mathrm{C}=\mathrm{O}) ;{ }^{1} \mathrm{H}-\mathrm{NMR}\left(400 \mathrm{MHz}, \mathrm{CDCl}_{3}\right) \delta$ : $7.934(1 \mathrm{H}, \mathrm{dd}, J=8.2,1.9 \mathrm{~Hz}, 5-\mathrm{H}), 7.505(1 \mathrm{H}, \mathrm{ddd}, J=1.9,8.2,8.8 \mathrm{~Hz}, 7-$ $\mathrm{H}), 7.416\left(2 \mathrm{H}, \mathrm{d}, J=8.8 \mathrm{~Hz}, 2^{\prime}, 6^{\prime}-\mathrm{Hs}\right), 7.048(1 \mathrm{H}, \mathrm{ddd}, J=8.2,8.2,1.0 \mathrm{~Hz}$, $6-\mathrm{H}), 7.038(1 \mathrm{H}, \mathrm{dd}, J=1.0,8.8 \mathrm{~Hz}, 8-\mathrm{H}), 6.964\left(2 \mathrm{H}, \mathrm{d}, J=8.8 \mathrm{~Hz}, 3^{\prime}, 5^{\prime}-\right.$ $\mathrm{Hs}), 5.436(1 \mathrm{H}, \mathrm{dd}, J=13.2,2.9 \mathrm{~Hz}, 2-\mathrm{H}), 3.114(1 \mathrm{H}, \mathrm{dd}, J=13.2,16.8 \mathrm{~Hz}$, $3-\mathrm{H}$ ax $), 2.866(1 \mathrm{H}, \mathrm{dd}, J=2.9,16.8 \mathrm{~Hz}, 3-\mathrm{H} \mathrm{eq}), 3.836\left(3 \mathrm{H}, \mathrm{s}, 4^{\prime}-\mathrm{OCH}_{3}\right)$; ${ }^{13} \mathrm{C}-\mathrm{NMR}\left(100 \mathrm{MHz}, \mathrm{CDCl}_{3}\right.$ ) $\delta: 192.182(\mathrm{C}-4), 161.607$ (C-9), 159.953 (C$\left.4^{\prime}\right), 136.115(\mathrm{C}-7), 130.751\left(\mathrm{C}-1^{\prime}\right), 127.701\left(\mathrm{C}-2^{\prime}, 6^{\prime}\right), 127.003(\mathrm{C}-5)$, 121.487 (C-6), 120.895 (C-10), 118.103 (C-8), 114.181 (C-3',5'), 79.319 (C-2), 55.231 (4'-OMe), 44.426 (C-3); HR-EI-MS m/z: 254.0938 (Calcd. for $\mathrm{C}_{16} \mathrm{H}_{14} \mathrm{O}_{3}$ : 254.0943); Anal. Calcd. for $\mathrm{C}_{16} \mathrm{H}_{14} \mathrm{O}_{3}$ : C, 75.57, H, 5.55; Found: C, $75.33, \mathrm{H}, 5.59$

$\mathbf{2}^{\prime}$-Hydroxy-4-methoxy[ $\alpha$ - $\left.\mathrm{D}_{1}\right]$ chalcone (2) Yellow solid, mp: 94 $95^{\circ} \mathrm{C} ;{ }^{1} \mathrm{H}-\mathrm{NMR}\left(300 \mathrm{MHz}, \mathrm{CDCl}_{3}\right) \delta: 12.931\left(1 \mathrm{H}, \mathrm{s}, 2^{\prime}-\mathrm{OH}\right), 7.918(1 \mathrm{H}, \mathrm{dd}$, $\left.J=1.5,8.0 \mathrm{~Hz}, 6^{\prime}-\mathrm{H}\right), 7.903(1 \mathrm{H}, \mathrm{s}, \beta-\mathrm{H}), 7.633(2 \mathrm{H}, \mathrm{d}, J=8.5 \mathrm{~Hz}, 2,6-\mathrm{Hs})$, $7.490\left(1 \mathrm{H}\right.$, ddd, $\left.J=1.5,7.8,8.5 \mathrm{~Hz}, 4^{\prime}-\mathrm{H}\right), 7.025\left(1 \mathrm{H}, \mathrm{dd}, J=1.0,8.2 \mathrm{~Hz}, 3^{\prime}-\right.$ H), $6.957(2 \mathrm{H}, \mathrm{d}, J=8.5 \mathrm{~Hz}, 3,5-\mathrm{Hs}), 6.942\left(1 \mathrm{H}\right.$, ddd, $J=1.0,7.8,8.0 \mathrm{~Hz}, 5^{\prime}-$ H), 3.869 (3H, s, 4-OMe); HR-FAB-MS (mNBA) $m / z: 255.0998$ (Calcd. for $\mathrm{C}_{16} \mathrm{H}_{13} \mathrm{O}_{3} \mathrm{D}_{1}: 255.1006$ ).

4'-Methoxy[3,3-D $]$ fllavanone (3) Colorless solid, mp: 87-88 ${ }^{\circ} \mathrm{C} ;{ }^{1} \mathrm{H}-$ NMR $\left(300 \mathrm{MHz}, \mathrm{CDCl}_{3}\right) \delta: 7.930(1 \mathrm{H}, \mathrm{dd}, J=1.8,8.2 \mathrm{~Hz}, 5-\mathrm{H}), 7.504(1 \mathrm{H}$, ddd, $J=1.8,7.5,8.0 \mathrm{~Hz}, 7-\mathrm{H}), 7.415\left(2 \mathrm{H}, \mathrm{d}, J=8.5 \mathrm{~Hz}, 2^{\prime}, 6^{\prime}-\mathrm{Hs}\right), 7.053(1 \mathrm{H}$, ddd, $J=1.0,7.5,8.2 \mathrm{~Hz}, 6-\mathrm{H}), 7.036(1 \mathrm{H}$, dd, $J=1.0,8.0 \mathrm{~Hz}, 8-\mathrm{H}), 6.963$ $\left(2 \mathrm{H}, \mathrm{d}, J=8.5 \mathrm{~Hz}, 3^{\prime}, 5^{\prime}-\mathrm{Hs}\right), 5.430(1 \mathrm{H}, \mathrm{s}, 2-\mathrm{H}), 3.836\left(3 \mathrm{H}, \mathrm{s}, 4^{\prime}-\mathrm{OMe}\right)$; HREI-MS m/z: 256.1078 (Calcd. for $\mathrm{C}_{16} \mathrm{H}_{12} \mathrm{O}_{3} \mathrm{D}_{2}: 256.1068$ ).

2'-Hydroxy $\left[\alpha\right.$ - $\left.\mathrm{D}_{1}\right]$ chalcone (8) Pale yellow solid, mp: $78-79^{\circ} \mathrm{C} ;{ }^{1} \mathrm{H}-$ NMR $\left(400 \mathrm{MHz}, \mathrm{CDCl}_{3}\right) \delta: 12.820\left(1 \mathrm{H}, \mathrm{s}, 2^{\prime}-\mathrm{OH}\right), 7.935(1 \mathrm{H}, \mathrm{dd}, J=1.5$, $\left.8.0 \mathrm{~Hz}, 6^{\prime}-\mathrm{H}\right), 7.932(1 \mathrm{H}, \mathrm{s}, \beta-\mathrm{H}), 7.695-7.664(2 \mathrm{H}, \mathrm{m}, \mathrm{Ar}-\mathrm{H}), 7.512(1 \mathrm{H}$, ddd, $\left.J=1.5,7.5,8.5 \mathrm{~Hz}, 4^{\prime}-\mathrm{H}\right), 7.475-7.425(3 \mathrm{H}, \mathrm{m}, \mathrm{Ar}-\mathrm{H}), 7.040(1 \mathrm{H}$, dd, $\left.J=0.5,8.5 \mathrm{~Hz}, 3^{\prime}-\mathrm{H}\right), 6.957$ (1H, ddd, $J=0.5,7.5,8.0 \mathrm{~Hz}, 5^{\prime}$-H); HR-EI-MS m/z: 225.0885 (Calcd. for $\mathrm{C}_{15} \mathrm{H}_{11} \mathrm{O}_{2} \mathrm{D}_{1}: 225.0900$ ). 
2'-Hydroxy-4-methoxy $\left[\boldsymbol{\alpha}, \mathbf{3}, \mathbf{5}-\mathrm{D}_{3}\right]$ chalcone (9) Yellow solid, mp: 89 $90{ }^{\circ} \mathrm{C} ;{ }^{1} \mathrm{H}-\mathrm{NMR}\left(300 \mathrm{MHz}, \mathrm{CDCl}_{3}\right) \delta: 12.933\left(1 \mathrm{H}, \mathrm{s}, 2^{\prime}-\mathrm{OH}\right), 7.920(1 \mathrm{H}, \mathrm{dd}$, $\left.J=1.8,8.0 \mathrm{~Hz}, 6^{\prime}-\mathrm{H}\right), 7.905(1 \mathrm{H}, \mathrm{s}, \beta-\mathrm{H}), 7.636(2 \mathrm{H}, \mathrm{s}, 2,6-\mathrm{Hs}), 7.493(1 \mathrm{H}$, ddd, $\left.J=1.8,7.5,8.5 \mathrm{~Hz}, 4^{\prime}-\mathrm{H}\right), 7.025\left(1 \mathrm{H}, \mathrm{dd}, J=1.0,8.5 \mathrm{~Hz}, 3^{\prime}-\mathrm{H}\right), 6.944$ (1H, ddd, $\left.J=1.0,7.5,8.0 \mathrm{~Hz}, 5^{\prime}-\mathrm{H}\right), 3.871(3 \mathrm{H}, \mathrm{s}, 4-\mathrm{OMe})$; HR-EI-MS $m / z$ : 257.1127 (Calcd. for $\mathrm{C}_{16} \mathrm{H}_{11} \mathrm{O}_{3} \mathrm{D}_{3}: 257.1131$ ).

[3,3-D, $\mathrm{D}_{2}$ Flavanone (10) Colorless solid, mp: $78-78.5^{\circ} \mathrm{C}$; ${ }^{1} \mathrm{H}-\mathrm{NMR}$ $\left(400 \mathrm{MHz}, \mathrm{CDCl}_{3}\right) \delta: 7.870(1 \mathrm{H}, \mathrm{dd}, J=1.8,8.0 \mathrm{~Hz}, 5-\mathrm{H}), 7.545-7.362$ (6H, m, Ar-H), 7.090-7.035 (2H, m, Ar-H), 5.488 (1H, s, 2-H); HR-EI-MS $m / z: 226.0959$ (Calcd. for $\mathrm{C}_{15} \mathrm{H}_{10} \mathrm{O}_{2} \mathrm{D}_{2}: 226.0963$ ).

4'-Methoxy $\left[3,3,3^{\prime}, 5^{\prime}-D_{4}\right]$ flavanone (11) Colorless solid, mp: 84 $85^{\circ} \mathrm{C}$; ${ }^{1} \mathrm{H}-\mathrm{NMR}\left(300 \mathrm{MHz}, \mathrm{CDCl}_{3}\right) \delta: 7.930(1 \mathrm{H}, \mathrm{dd}, J=1.8,8.0 \mathrm{~Hz}, 5-\mathrm{H})$, 7.505 (1H, ddd, $J=1.8,7.5,8.0 \mathrm{~Hz}, 7-\mathrm{H}), 7.415$ (2H, s, 2',6'-Hs), 7.050 $(1 \mathrm{H}$, ddd, $J=1.0,7.5,8.0 \mathrm{~Hz}, 6-\mathrm{H}), 7.035(1 \mathrm{H}$, dd, $J=1.0,8.0 \mathrm{~Hz}, 8-\mathrm{H})$, $5.430(1 \mathrm{H}, \mathrm{s}, 2-\mathrm{H}), 3.830\left(3 \mathrm{H}, \mathrm{s}, 4^{\prime}\right.$-OMe $)$; HR-EI-MS $m / z: 258.1195$ (Calcd. for $\mathrm{C}_{16} \mathrm{H}_{10} \mathrm{O}_{3} \mathrm{D}_{4}: 258.1194$ ).

\section{References}

1) Kuhnau J., World Rev. Natr. Diet., 24, 117-191 (1976).

2) Hertog M. G. L., Feskens E. J. M., Hollman P. C. H., Katan M. B., Kromhout D., Lancet, 342, 1007-1011 (1993).

3) Heim K. E., Tagliaferro A. R., Bobilya D. J., J. Nutr. Biochem., 13, $572-584$ (2002)

4) Bear W. L., Teel R. W., Anticancer Res., 20, 3609-3614 (2000).

5) Lasker J. M., Huang M. T., Conney A. H., J. Pharmacol. Exp. Ther, 229, $162-170$ (1984).

6) Moon J. Y., Lee D. W., Park K. H., Xenobiotica, 28, 117-126 (1998).
7) Datla K. P., Christidou M., Widmer W. W., Rooprai H. K., Dexter D. T., NeuroReport, 12, 3871-3875 (2001).

8) Takanaga H., Ohnishi A., Yamada S., Matsuo H., Morimoto S., Shoyama Y., Ohtani H., Sawada Y., J. Pharmacol. Exp. Ther., 293 $230-236$ (2000).

9) Choi C. H., Sun K. H., An C. S., Yoo J. C., Hahm K. S., Lee I. H., Sohng J. K., Kim Y. C., Biochem. Biophys. Res. Commun., 295, 832840 (2002).

10) Kagawa H., Kimura R., Konda Y., Takeda K., Sakabe C., Nakagawa A., Sato N., Harigaya Y., Ohta S., Hirobe M., Sixth North American ISSX Meeting, Raleigh, USA, International society for the study of xenobiotics proceedings, 6, p. 142 (1994).

11) Hakamatsuka T., Hashim M. F., Ebizuka Y., Sankawa U., Tetrahedron 47, 5969-5978 (1991).

12) Rasku S., Wähälä K., Koskimies J., Hase T., Tetrahedron, 55, 3445 3454 (1999).

13) Rasku S., Wähälä K., Tetrahedron, 56, 913-916 (2000).

14) Silva A. M. S., Price W. A., Cavaleiro J. A. S., Tetrahedron Lett., 34 5657-5660 (1993).

15) Kagawa H., Harigaya Y., The 121st Annual Meeting of the Pharmaceutical Sciences of Japan, Sapporo, Japan, Abstract of papers-2, p. 83 (2001).

16) Mazur W., Fotsis T., Wähälä K., Ojala S., Salakka A., Adlercreutz H., Anal. Biochem., 233, 169-180 (1996).

17) Doshi A. G., Ghiya B. J., Curr. Sci., 55, 502-503 (1986).

18) Imafuku K., Honda M., McOmie J. F. W., Synthesis, 199-201 (1987). 